\title{
THE RELATIONSHIP BETWEEN KNOWLEDGE CAPITAL, SPILLOVER EFFECTS AND LABOR PRODUCTIVITY ${ }^{[*]}$
}

\author{
Mustafa Nedim SÜALP ${ }^{[* *}$ \\ Cemil Faruk DURMAZ ${ }^{[* * *}$
}

\begin{abstract}
In growth literature the part and the variations of the growth rates unexplained by the changes in the amount of labor and capital, named as Solow Residual, has been continuing to be one of the main concerns. Technological advances and improvements in human capital have been the main candidates in investigating the sources of the unexplained part of the growth phenomenon. However the channels through which technology is transferred among countries still need more investigation. Most part of the literature is focused on the Total Factor Productivity (TFP), the main determinants of which are considered to be the research and development (R \& D) and human capital. More recently spillover effects as the way to transfer the technology through the import of capital and Foreign Direct Investment (FDI) have become the central theme. Spillover effects through capital goods imports and domestic R\&D capital stock on labor productivity are empirically investigated in this study for 23 countries between 2002 and 2011. Results of panel data analysis indicated that technology transfer is significant and positive for a large and heterogeneous sample. However, capital goods imports do not cause a knowledge transfer from G7 economies to countries with relatively and significantly lower level of productivity. The paper is expected to contribute the literature by using labor productivity instead of total factor productivity when the effects of externalities are investigated in samples with different set of countries.
\end{abstract}

Keywords: Total Factor Productivity, Labor Productivity, R\&D Capital, Spillover Effects

JEL Classification: D24, O32, O33

\section{BİLGİ SERMAYESİ, YAYILMA ETKİSİ VE EMEK VERIMMLİLİĞİ ARASINDAKİ İLİŞKİ}

Özet

Büyüme literatüründe büyüme oranlarının ve bu oranlardaki oynaklıkların, Solow Artığı olarak isimlendirilen, sermaye ve emek miktarlarınca açıklanamayan kısmı halen temel sorunlardan biri olmaya

[*] This paper was adapted from Cemil Faruk Durmaz's master thesis at Marmara University Dept of Economics submitted in May 2016.

[**] Assistant Ass. Prof. Dr. Department of Economics, Göztepe Campus, Istanbul, nsualp@marmara.edu.tr

[***] PhD Candidate, Marmara University Department of Economics 
devam etmektedir. Büyüme olgusunun bu açıklanamayan kısmının kaynaklarının araştırılmasında teknolojik gelişmeler ve beşeri sermayedeki ilerlemeler en önemli adaylar olarak belirmektedir. Ancak teknolojinin ülkeler arasında transfer edilme kanalları halen açıklanmaya muhtaç bulunmaktadır. $\mathrm{Bu}$ konudaki literatürün çoğu araştırma ve geliştirme (ARGE) ve beşeri sermayenin asıl belirleyenleri olduğu düşünülen Toplam Faktör Verimliliği (TFV)üzerinde odaklanmaktadır. Son dönemlerde sermaye mallarının ithalatı ve yabancı sermaye yatırımları aracılığıyla teknoloji transferinin bir kanalı olarak Yayılma Etkisi merkezi bir konum almıştır. Bu çalışmada sermaye malları ithalatı yoluyla yayılma etkisi ve yurt içi ARGE sermayesinin emek verimliliği üzerindeki etkisi 2002 - 2011 yılları arasında 23 ülke için ampirik olarak incelenmiştir. Panel veri analizinin sonuçları büyük ve heterojen örneklem için teknoloji transferinin anlamlı ve olumlu olduğunu göstermiştir. Ancak sermaye malları ithalatı yoluyla oluşan teknoloji transferi G7 ekonomilerinden önemli ölçüde daha düşük emek verimliliği olan ülkelere doğru anlamlı bir etki oluşturmamaktadır. Bu çalışma, toplam faktör verimliliği yerine emek verimliliğini farklı ülke gruplarında dışsallığın etkisini ölçmekte kullanarak literature katkıda bulunmayı amaçlamaktadır.

Anahtar Kelimeler: Toplam Faktör Verimliliği, Emek Verimliliği, ARGE Sermayesi, Yayılma Etkisi

JEL Sınıflaması: D24, O32, O33

\section{I.Introduction}

In growth literature the part and the variations of the growth rates unexplained by the changes in the amount of labor and capital, named as Solow Residual, has been continuing to be one of the main concerns. Technological advances and improvements in human capital have been the main candidates in investigating the sources of the unexplained part of the growth phenomenon. The first generation of endogenous growth theories, pioneered by Paul Romer and others, mainly focused on the closed economies investigating the effects of human capital, externalities and learning by doing processes.

However the channels through which technology is transferred among countries still need more investigation. Most part of the literature is focused on the Total Factor Productivity (TFP), the main determinants of which are considered to be the research and development (R\&D) and human capital. More recently spillover effects as the way to transfer the technology through the import of capital goods and Foreign Direct Investment (FDI) have become the central theme.

Definitions and the boundaries of technology shed light on new and various types of research in the literature of growth economics. Technical knowledge cannot just be categorized based on its excludability and rivalry. In a more globalized world, either the knowledge capital embedded in high technological products or the information around the world can be excluded easily. This is the reason why technology is considered to be partially excludable. The argument on this issue leads to another notion, called externality. Since new information produced in any industry or country can be obtained by the others, it is argued that these innovations may create spillover effects throughout the whole economy. The issue of how the spillover effects could be measured has been one of the several times in the empirical literature. Imports and foreign direct investment 
(FDI) are regarded as the most common channels for technology transfer. It is argued that firms share information with each other via mergers and acquisitions through which countries may be able to receive new information contained in the imports of capital goods.

Spillover effects through capital goods imports and domestic R\&D capital stock on labor productivity, instead of TFP, are empirically investigated in this study for 23 countries between 2002 and 2011. Results of panel data analysis indicated that technology transfer is significant and positive for a large and heterogeneous sample. Externalities also exist between G7 economies and countries with low labor productivity. However, capital goods imports do not cause a knowledge transfer from G7 economies to countries with relatively and significantly lower level of productivity.

\section{Literature Review}

In Coe and Helpman ${ }^{1}$, two extreme cases are considered. In the first one, a country's R\&D efforts are originated from domestic capabilities only and in the second one, it is based on only foreign countries' $R \& D$ resources. Foreign $R \& D$ capital stock is calculated in two steps. First, by summing up the domestic R\&D capital stocks of each countries' trading partners. It should be noted that Coe and Helpman constructed a panel data analysis for 22 OECD countries between 1971 and 1990. A cointegration analysis is conducted to exploit the long run relationship between variables. Unit root test shows that variables are non-stationary in the paper. Cointegration between other variables and TFP is found. Foreign R\&D has a greater impact on most of the smaller countries when domestic R\&D has a larger impact on larger ones. So evidence (elasticity values) shows that direction of the technology transfer is mostly from larger countries to smaller ones. Coe, Helpman and Hoffmaister ${ }^{2}$ proves that imports of machinery and equipment is more efficient than its alternatives when it comes to increase total factor productivity via trade. Another different explanatory variable is used in this paper is market growth. By using the change in the log of a weighted average of industrialized countries' GDP, it is shown that market growth is not significantly different from zero. It is proven that results of this work shows R\&D spillovers, not an access to markets in growth. As a result, in Coe, Helpman and Hoffmaister ${ }^{3}$, it is found that on average a $1 \%$ increase in $\mathrm{R} \& \mathrm{D}$ capital stock of developed economies increase the output of developing countries by $0.06 \%$ via trade.

In $\mathrm{Xu}$ and Wang ${ }^{4}$, they also argue that using machinery and equipment imports as a weighting scheme gives better results. The share of capital imports are volatile in countries' total imports because they are consisting of consumption goods too. Results may be misleading since it is unlikely to transfer technology from various types of final goods. They also used the main

\footnotetext{
${ }^{1}$ Helpman E., David T. Coe, "International R\&D Spillovers", European Economic Review, 859 - 887, 1995.

${ }^{2}$ Helpman E., David T. Coe, "North-South R\&D Spillovers", The Economic Journal, 134-149, 1997.

${ }^{3}$ Helpman and Coe, 1997, Ibid.

Xu Bin, J. W., "Capital Goods Trade and R\&D Spillovers in the OECD", The Canadian Journal of Economics, 1258$1274,1999$.
} 
equation in Coe and Helpman ${ }^{5}$ as a model and tested both weighting types. Results showed that, TFP is correlated with foreign $\mathrm{R} \& \mathrm{D}$ weighted by capital goods imports when it is not with foreign R\&D weighted by total imports.

In Bruno van Pottelsberghe de la Potterie (PL) ${ }^{6}$, FDI was also used as a weighted method. Paper also argued that $\mathrm{CH}$ method for weighting foreign $\mathrm{R} \& \mathrm{D}$ has an aggregation bias. Trade, inward and outward FDI was used as independent variables. Domestic R\&D of country $j$ is divided by same country's GDP and weighted by flow of imports of goods and services of country $i$ from $j$ is used constructing foreign R\&D of country i via trade. As a result, inward FDI has no significant effects on TFP. There is no technology transfer through inward FDI. On the other hand, the output elasticity of outward FDI flows is significant and positive. Results also show that outward FDI and imports reinforce each other.

In Bitzer and Kerekes ${ }^{7}$, (2008), a new evidence contradicts with the Potterie and Lichtenberg was presented. They found out that inward FDI actually has a positive and significant effect on technology. They also emphasized that outward FDI does not provide technology transfer. This result contradicts with PL (2001). It is possible to say that FDI may transfer technology rather than functioning as a trojan horse. The difference between results of these two studies' can be interpreted by examining their samples. Since PL (2001) used a sample consisting of developed OECD economies, it is plausible to see why they have found a contradicting result.

In Coe, Helpman and Hoffmaister ${ }^{8}$ (2008) the model constructed in 1995 was again estimated with an expanded sample using DOLS. The new sample consists of 24 countries between 1971 and 2004. With a larger sample, elasticity of domestic R\&D capital decreases in the G7 economies when it rises in non-G7 countries. Evidence confirms CH (1995) with more robust results. Human capital is also added as a significant independent variable. Alternative definitions for foreign $\mathrm{R} \& \mathrm{D}$ capital stock is also estimated. In the first one, domestic $\mathrm{R} \& \mathrm{D}$ capital of trading partners is weighted by bilateral import share weighted average as in $\mathrm{CH}$ (1995). In the second one, method proposed in Pottelsberghe de la Potterie (2001) is used to weight foreign R\&D capital. As the last option, simple average of trading partners' is used to weight. The results suggest that bilateral import weights performs better than Pottelsberghe de la Potterie (2001) method. Simple average shows the worst performance among those three.

This paper is composed as follows; first data and methodology is explained, secondly descriptive statistics are presented, empirical model and empirical results can be found in third and fourth section. Concluding remarks are drawn in the final section.

$5 \quad$ Coe and Helpman, 1995, Ibid.

6 Van Pottelsberghie Bruno, F. L., "Does Foreign Direct Investment Transfer Technology Across Borders?" The Review of Economics and Statistics, 490-497, 2001.

7 Bitzer Jürgen, M. K., “Does Foreign Direct Investment Transfer Technology Across Borders?” Economic Letters 100, 355-358, 2008.

8 Helpman E., Coe, D. T. and Hoffmaister, W., "International R\&D Spillovers and Institutions", NBER Working Paper Series, 14069, 2008. 


\section{Data and Methodology}

Empirical research is mainly based on research and development expenditures and its relationship between productivity in 23 countries between 2002 and 2011. There are 230 observations. Independent variables in the model are domestic and foreign R\&D capital stock, fixed capital formation. Dependent variable is labor productivity. The Sample is represented in two parts in Table 1 and 2. In "All Economies" table, all of the countries in the sample can be observed. In the second table, descriptive statistics for countries with low labor productivity are presented. There is unilateral technology transfer from G7 economies to countries with labor productivity below average. ${ }^{9}$ Data for R\&D variables, Real GDP, fixed capital formation are taken from OECD Database. Data for total employment is obtained from Total Economy Database. Data for Machinery and Transport Equipment Import ${ }^{10}$ is taken from UN Comtrade. Raw data for the R\&D Capital Stock is the Private Sector R\&D Expenditures.

Table I: Countries in "All Economies" Sample

\begin{tabular}{|c|c|c|c|}
\hline G7 & \multicolumn{3}{|c|}{} \\
\hline Canada & Australia & Israel & Slovenia \\
\hline France & Austria & Korea & Turkey \\
\hline Germany & Belgium & Mexico & \\
\hline Italy & CzechRepublic & Netherlands & \\
\hline Japan & Finland & Norway & \\
\hline United Kingdom & Spain & Poland & \\
\hline United States & Hungary & Portugal & \\
\hline
\end{tabular}

Table 2: Countries with Low Labor Productivity I I

\begin{tabular}{|c|c|c|}
\hline Czech Republic & Korea & Portugal \\
\hline Israel & Mexico & Slovenia \\
\hline Hungary & Poland & Turkey \\
\hline
\end{tabular}

The variables used in this research are constructed in different methods. Explanatory variables are grouped in two sections and it can be seen in Figure 3. All variables are real with 2010 as base year. Bilateral Machinery and Equipment Imports are taken in current values. They are transformed into real variables with 2010 as base year using GDP Deflator. All variables are in US dollars. Total Employment is the number of people who are employed and it is in thousands when

9 Spain was excluded because it is an outlier. The graph can be found in Appendix B.

11 Even though China and Russia are not in the sample, descriptive statistics for these two countries are also presented. They are not included in the sample because they are outliers, scatter plot can be found in the Appendix B. 
all the other variables are in millions. Domestic R\&D capital stock is calculated using perpetual inventory method on R\&D expenditures between 2002 and 2011. ${ }^{12}$ Notation for all variables is presented in Table 3.

Table 3: Notation for Variables

\begin{tabular}{|c|c|}
\hline Labor Productivity & $\mathrm{Y}_{\text {it }} / \mathrm{L}_{\text {it }}$ \\
\hline Domestic R\&D Capital & $\mathrm{R}_{\mathrm{it}}$ \\
\hline Foreign R\&D Capital & $\mathrm{F}_{\mathrm{ijt}}$ \\
\hline Physical Capital & $\mathrm{K}_{\mathrm{it}}$ \\
\hline
\end{tabular}

Labor productivity is calculated as the ratio of Real GDP to total employment. Domestic R\&D Capital Stock is the cumulative R\&D expenditures of the countries in the sample. This variable is used as a stock rather than a flow. Because the fluctuations in flow variable may result in a biased result. Secondly, since there are data limitations in R\&D expenditure, stock variable is useful to capture the cumulative effect. It is also plausible to have a stock variable to measure the knowledge capital. Agents in the economy do not only use the knowledge capital produced in a certain time period, they would also use all the knowledge they can gather from the past periods. The other domestic variable is physical capital. It is used to capture the effect of physical capital on labor productivity. An increase in the amount of capital may give rise to increase in efficiency of labor. As the capital stock rises, this might also prevent the diminishing labor productivity. It should also be noted that machines with higher efficiency would make labor more productive. It is expected that change in the physical capital stock would have a positive effect on productivity.

Foreign $\mathrm{R} \& \mathrm{D}$ Capital is used to capture the spillover effect (externalities). $\mathrm{F}_{\mathrm{ijt}}$ represents the foreign R\&D capital stock and i stands for the importer when $\mathrm{j}$ shows the exporter country. $\mathrm{I}_{\mathrm{ijt}}$ is the bilateral machinery and transport eq. imports (capital good import) of the country i from country j. Foreign R\&D Capital Stock is calculated as follows;

$\mathrm{F}_{\mathrm{ijt}}=\sum_{t=2002}^{\mathrm{t}=2011} \frac{I_{i j \mathrm{t}}}{y_{i t}} R_{j \mathrm{t}}$

$\mathrm{R}_{\mathrm{j} \text { i }}$ is the domestic R\&D capital stock of the exporter country. Each country's R\&D capital stock is multiplied with the bilateral capital goods exports to another country to importer's GDP ratio. This variable is the foreign capital stock of the importer country.

\section{Descriptive Statistics}

Mean values and standard deviations for two samples are presented in Table 4 and Table 5 . Mean values for all variables except foreign $R \& D$ capital are higher in large sample because the

12 Detailed calculation of PIM (Perpetual Inventory Method) can be found in Appendix A. 
major economies are excluded in the second sample. Mean for foreign R\&D capital is greater in countries with low productivity since there is one-way transfer from only G7. Standard deviation of all variables are greater in "All Economies" sample. This outcome is plausible since large sample is more heterogonous.

Table 4: Descriptive Statistics for All Economies

\begin{tabular}{|c|c|c|c|c|c|}
\hline Variable & Obs & Mean & Std. Dev. & Min & Max \\
\hline & & & & & \\
\hline LP & 230 & 1.841412 & 0.11879 & 1.569735 & 2.066621 \\
\hline & & & & & \\
\hline BRD & 230 & 4.755623 & 0.697114 & 3.561365 & 6.389769 \\
\hline & & & & & \\
\hline FRD & 230 & 2.565731 & 0.475148 & 1.704621 & 3.887333 \\
\hline & & & & & \\
\hline CAP & 230 & 5.240652 & 0.532143 & 4.059181 & 6.512911 \\
\hline
\end{tabular}

LP: Labor Productivity, BRD: Domestic R\&D Capital Stock, FRD: Foreign R\&D Capital Stock, CAP: Physical Capital

Table 5: Descriptive Statistics for Unilateral Technology Transfer

\begin{tabular}{|l|l|l|l|l|l|}
\hline Variable & Obs & Mean & Std. Dev. & Min & Max \\
\hline & & & & & \\
\hline LP & 90 & 1.713889 & .0645683 & 1.569735 & 1.818141 \\
\hline & & & & & \\
\hline BRD & 90 & 4.200825 & .5007833 & 3.561365 & 5.395854 \\
\hline & & & & & \\
\hline FRD & 90 & 2.731027 & 0.548377 & 1.793824 & 3.872477 \\
\hline & & & & & \\
\hline CAP & 90 & 4.949199 & 0.4620536 & 4.059181 & 5.665515 \\
\hline
\end{tabular}

LP: Labor Productivity, BRD: Domestic R\&D Capital Stock, FRD: Foreign R\&D Capital Stock, CAP: Physical Capital

\section{Empirical Model}

The model is based on Coe and Helpman ${ }^{13}$ (1993). In their paper, Coe and Helpman formulated an empirical model in order to estimate Total Factor Productivity. A detailed explanation of theoretical model which was presented in Grossman and Helpman (1991) can also be found

13 Helpman E., and David T. Coe,., International R\&D Spillovers. Working Paper International Bureau of Economic Research, 1993. 
in Appendix C. Coe and Helpman used domestic R\&D capital and foreign R\&D capital as independent variables. In this research, the empirical model is as follows;

$\log L P_{i t}=a_{i}+\operatorname{logBRD} D_{i t}+\log \mathrm{CAP}_{\text {it }}+\varepsilon_{\text {it }}$

$\log \mathrm{LP}_{\mathrm{it}}=\alpha_{\mathrm{i}}+\log \mathrm{BRD}_{\mathrm{it}}+\log \mathrm{CAP}_{\mathrm{it}}+\log \mathrm{FRD}_{\mathrm{it}}+\varepsilon_{\mathrm{it}}$

First equation represents a closed economy. There is no foreign $\mathrm{R} \& \mathrm{D}$ capital stock in this case. Spillover effects are captured in the second equation. This is a model for open economy. All variables are in logarithmic forms. This model is differentiated from Coe and Helpman ${ }^{14}$. First, dependent variable is chosen as labor productivity rather than total factor productivity. Second, capital goods import are used to weight the foreign $\mathrm{R} \& \mathrm{D}$. The reasoning behind this choice is explained in Data and Methodology Section. Finally, Fixed Capital Formation is used as another domestic variable in order to control for the change in the physical capital stock of countries. $\varepsilon_{\text {it }}$ stands for the error term and $\alpha_{i}$ is the intercept.

\section{Empirical Analysis}

Closed and open economy models are estimated for both samples. Hausman test results indicated that fixed effect model should be used. It is found that there is auto correlation, cross-sectional dependency and heteroscedasticity problem in the samples. In order to, control for these problems different types of estimation methods can be chosen. Parks-Kmenta, BeckKatz and Driscoll- Kraay estimators are suitable, since all of them can control these three problems simultaneously. However, Parks-Kmenta and Beck-Katz would give biased results when number of cross sections are greater than the time period. On the other hand, DriscollKraay gives more unbiased results with robust control for standard errors even when $\mathrm{N} \square(\rightarrow) \infty$. That's why Driscoll-Kraay is a more suitable estimation method for the sample in this research. Driscoll-Kraay's method is the same as the Newey-West estimator which is used for timeseries data. This method also controls for heteroscedasticity and autocorrelation. This method gives unbiased standard error estimations without taking the number of cross sections into consideration. Driscoll-Kraay estimation is implemented and the results are presented in the Table 6 and Table 7.

Effects of all explanatory variables on labor productivity can be observed for All Economies sample in Table 6. All variables are significant. Domestic sector R\&D capital stock has the highest coefficient when foreign R\&D capital has the lowest. In Table 7, it can be seen that highest coefficient belongs to the physical capital. Foreign R\&D Capital stock turns out to be insignificant in this sample.

14 Ibid. 
Table 6: Driscoll-Kraay F.E. Estimation - All Economies

\begin{tabular}{|c|c|c|}
\hline & $(1)$ & $(2)$ \\
\hline VARIABLES & LP & LP \\
\hline BRD & $0.202^{* * *}$ & $0.194^{* * *}$ \\
\hline & $(0.039)$ & $(0.036)$ \\
\hline CAP & $0.161^{* * *}$ & $0.157^{* * *}$ \\
\hline & $(0.040)$ & $(0.035)$ \\
\hline FRD & & $0.0214^{* * *}$ \\
\hline & & $(0.0057)$ \\
\hline Observations & 230 & 230 \\
\hline Number of groups & 23 & 23 \\
\hline within R-squared & 0.5605 & 0.5684 \\
\hline
\end{tabular}

Std. Err. in parentheses

${ }^{* * *} \mathrm{p}<0.01,{ }^{* *} \mathrm{p}<0.05,{ }^{*} \mathrm{p}<0.1$

Impact of physical capital on productivity in the sample consists of countries with low labor productivity and this result is plausible since these countries do not use high technology production as much as major economies do. On the other hand, the large sample has big economies alongside with others so $\mathrm{R} \& \mathrm{D}$ capital stock is more effective. The most intriguing result is about the coefficient of foreign $\mathrm{R} \& \mathrm{D}$ capital. There is bilateral technology transfer in All Economies sample when there is transfer only from G7 economies to countries with low productivity.

There is no significant effect of G7's R\&D capital stock on the countries in small sample via capital goods. It is plausible to say that countries which are not "developed enough" to absorb the influx of information from countries which are highly advanced, cannot use this externality to increase their productivity. It should be noted that this result is valid for "unilateral technology transfer".

\section{Conclusion}

This research concluded that domestic, foreign knowledge capital and physical capital have significant and positive effects on labor productivity in a large sample consists of 23 economies for 10 years when there is bilateral technology transfer. However there is no significant technology transfer from G7 countries to economies with low labor productivity. Impact of physical capital is also greater than the impact of $\mathrm{R} \& \mathrm{D}$ capital in the second sample. This result could arise because of the structural dissimilarities and differences in education level between countries. It is plausible to say that countries which are leading in similar industries, technology and productivity levels have a greater absorptive capacity. Education (human capital) is also crucial to increase absorptive capacity. The critical part of this research is the comparison of two different samples. "All Economies" sample is large, heterogeneous and there is bilateral technology transfer. 
Spillover effects are exist in this sample. On the other hand, countries with low productivity are not able to absorb the knowledge transfer from G7 economies. It should be noted that there is unilateral technology transfer in this small sample.

Table 7: Driscoll-Kraay F.E. Estimation - Unilateral Technology Transfer

\begin{tabular}{|l|l|l|}
\hline & $(1)$ & $(2)$ \\
\hline VARIABLES & LP & LP \\
\hline BRD & $0.191^{\star * *}$ & $0.181^{* * *}$ \\
\hline & $(0.039)$ & $(0.037)$ \\
\hline CAP & $0.230^{* * *}$ & $0.234^{* * *}$ \\
\hline & $(0.052)$ & $(0.050)$ \\
\hline FRD & & 0.0204 \\
\hline & & $(0.010)$ \\
\hline Observations & 90 & 90 \\
\hline Number of groups & 9 & 9 \\
\hline within R-squared & 0.6738 & 0.6795 \\
\hline
\end{tabular}

Std. Err. in parentheses

${ }^{\star * *} \mathrm{p}<0.01,{ }^{* *} \mathrm{p}<0.05,{ }^{\star} \mathrm{p}<0.1$

\section{References}

XU Bin, J. W. Capital Goods Trade and R\&D Spillovers in the OECD. The Canadian Journal of Economics, 1258-1274, 1999.

VAN POTTELSBERGHE Bruno, F. L., Does Foreign Direct Investment Transfer Technology Across Borders? The Review of Economics and Statistics, 490-497, 2001.

HELPMAN E., Coe, D. T. \& Hoffmaister, W., International R\&D Spillovers and Institutions. NBER Working Paper Series, 14069, 2008

HELPMAN E., David T. Coe,., International R\&D Spillovers. Working Paper International Bureau of Economic Research, 1993

HELPMAN E., David T. Coe, International R\&D Spillovers. European Economic Review, 859 - 887, 1995

HELPMAN E., David T. Coe, North-South R\&D Spillovers. The Economic Journal, 134-149, 1997

HELPMAN E., David T. Coe, International R\&D Spillovers and Institutions. IMF Working Paper, 2008

HELPMAN E., Gene M. GROSSMAN, Quality Ladder in the Theory of Growth. The Review of Economic Studies, 43-61, 1991

HELPMAN E., G. M., Quality Ladders in the Theory of Growth. The Review of Economic Studies, 43-61, 1991

DRISCOLL J., A. C., Consistent covariance matrix estimation with spatially dependent data. Review of Economics and Statistics, 549-560, 1998

BITZER Jürgen, M. K., Does Foreign Direct Investment Transfer Technology Across Borders? Economic Letters 100, 355-358, 2008 
BECK. N., J. K., Nuisance vs. Substance: Specifiying and Estimating Time Series Cross Section Models. Political Analysis 6, 1-36, 1996

PARKS, R. W., Efficient Estimation of a System of Regression Equation When Distrubance are Both Serially and Contemporaneously Correlated. Journal of the American Statistical Association 62, 500-509, 1966

ROMER, P. M., Increasing Returns and Long-Run Growth. Journal of Political Economy, 1002-1037, 1986

ROMER, P. M., Endogenous Technological Change. Journal of Political Economy, 1990

SOLOW, R. M., A Contribution to the Theory of Economic Growth. The Quarterly Journal of Economics, 65-94, 1956 


\section{Appendix A}

In this study, domestic $\mathrm{R} \& \mathrm{D}$ capital stocks of the countries are calculated using the perpetual inventory method. Capital stock for the initial year is calculated in the first equation. E0 is the $R \& D$ expenditure in the first year of the data. It is the data for 2002 in this case. $g$ stands for the average annual logarithmic growth of $\mathrm{R} \& \mathrm{D}$ expenditures in all years and $\delta$ is the depreciation rate which is $10 \% .{ }^{15}$

$\mathrm{R}_{0}=\mathrm{E}_{0} /(\mathrm{g}+\delta)$

In the second equation, $R_{t}-1$ stands for the capital stock in year $t-1$ and $E_{t}$ denotes the expenditure on $R \& D$ in year t. (1- $\delta$ ) represents the remaining capital stock after the depreciation rate.

$\mathrm{R}_{\mathrm{t}}=(1-\delta) \mathrm{R}_{\mathrm{t}}-1+\mathrm{E}_{\mathrm{t}}$

It should be noted that $R_{t}$ for each year is shown as $B R D$ in this paper which stands for Domestic $\mathrm{R} \& \mathrm{D}$ capital stock. Flow variables such as $\mathrm{R} \& \mathrm{D}$ expenditure can be turned into stock variables by using perpetual inventory method.

\section{Appendix B}

Figure B. I: Scatter Plot for All Economies

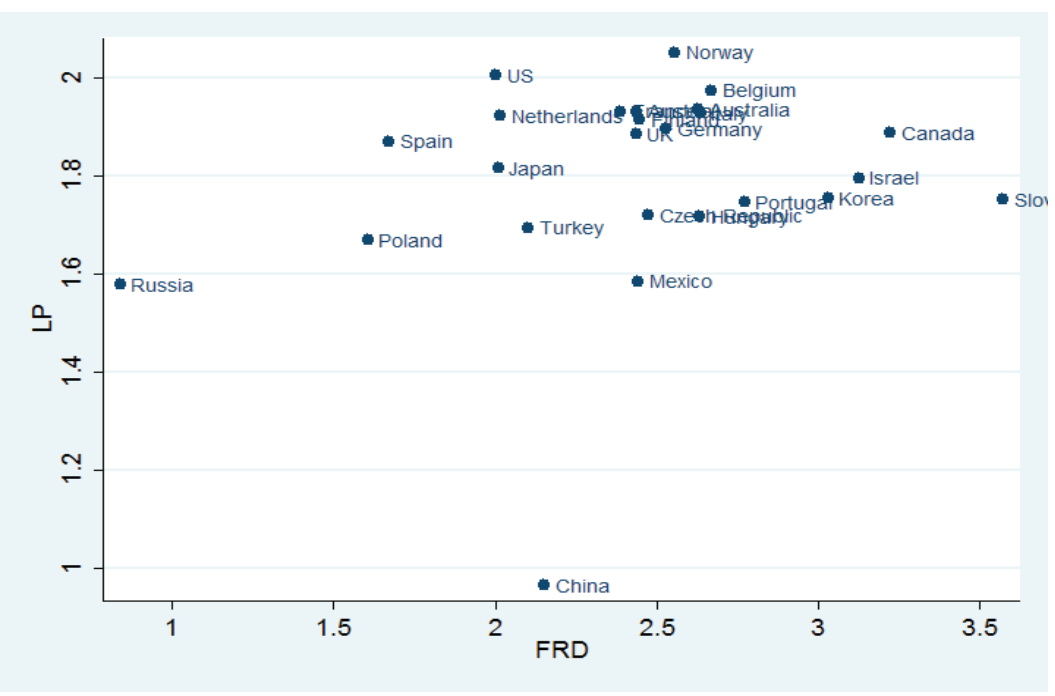

15 Deprecation rate is chosen as $10 \%$ based on M.Henry, R.Kneller and C.Milner (2009). It is generally determined as $5 \%, 10 \%$ or $15 \%$ in the literature. 
Figure B.2: Scatter Plot for Countries with Low Productivity (Unilateral Technology Transfer)

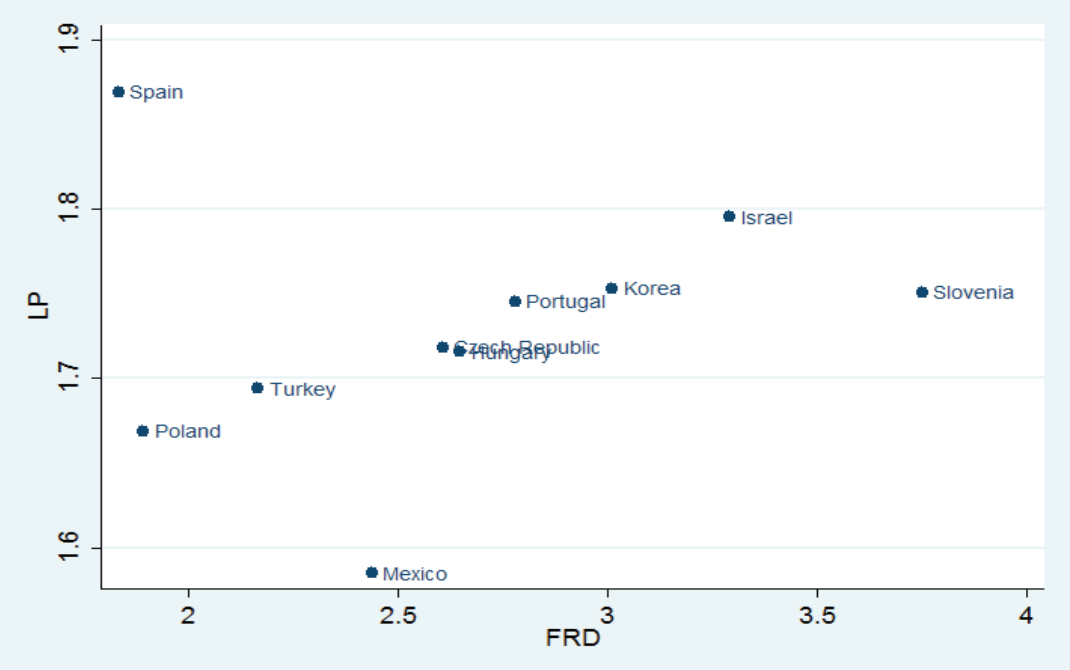

\section{Appendix C: Theoretical Model}

The model created in Grossman and Helpman ${ }^{16}$ is used as a base for this research. The theoretical model is mainly explaining how research and development efforts function and its effects on economic growth. There is monopolistic competition in the R\&D market. The innovation efforts of the agents in the economy is vertically differentiated. It is called quality ladder approach and it is more realistic comparing to a horizontal one in case of a R\&D based model. Breakdown of the model is represented in Figure 2.

Figure C.I: Market Composition

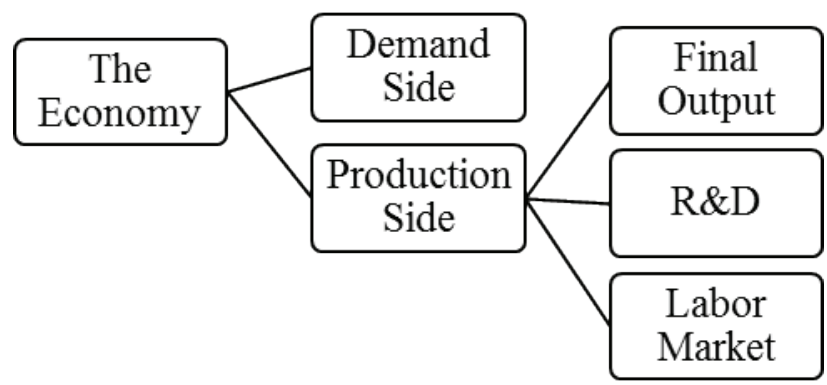

16 Grossman, Gene M. and Helpman E., "Quality Ladder in the Theory of Growth", The Review of Economic Studies, 43-61, 1991 


\section{Demand Side}

Consumers optimize their utility subject to an intertemporal budget constraint. Quality of goods they demand is defined by an innovation parameter. Since this is a vertical model, number of innovations is also considered. The intertemporal utility function is as follows;

$\mathrm{U}=\int_{0}^{\infty} e^{-p t} \log u(t) d t$

$\operatorname{logu}(\mathrm{t})=\int_{0}^{1} \log \left[\sum_{j} q_{j \mathrm{t}}(\mathrm{u}) d_{j \mathrm{t}}(\mathrm{u})\right] d \mathrm{u}$

In these equations, $\mathrm{q}_{j}(\mathrm{u})=\Lambda^{j}$ stands for the quality of a good and $\Lambda^{j}$ represents how many times the product is innovated. Consumption of quality $\mathrm{j}$ of good $\mathrm{u}$ is shown as; $\mathrm{d}_{\mathrm{jt}}(\mathrm{u})=\mathrm{E}(\mathrm{t}) / p_{j \mathrm{t}}$ ( $\mathrm{u}$ ) . This equation is simply the demand function. The intertemporal budget constraint is given below;

$\int_{0}^{\infty} e^{-R(t)} E(t) d t$

Flow of spending at time $\mathrm{t}$ is shown as $\mathrm{E}(\mathrm{t})=\int_{0}^{1} \sum_{j} p_{j \mathrm{t}}(\mathrm{u}) d_{j \mathrm{t}}(\mathrm{u}) d \mathrm{u}$ when $\mathrm{R}(\mathrm{t})$ is the cumulative interest rate. Solution to consumer's optimization problem is solved with the help of a Hamiltonian Function;

$\mathrm{H}=\int_{0}^{\infty} e^{-p t}\left\{\ln E(t)+\int_{0}^{1} \ln q(\mathrm{u})-\ln p(\mathrm{w}) d \mathrm{u}\right\} d t+\mu(\mathrm{t}) \int_{0}^{\infty} e^{-R(t)} E(t) d t$

The second terms (with $\mathrm{q}$ and $\mathrm{p}$ ) in the first parenthesis can be ignored since they do not depend on t. This also means that consumer has no influence on these variables. The consumer makes his/her maximization decision in two steps. First he/she allocates $E(t)$ to maximize $u(t)$, then maximizes the Hamiltonian function with respect to time. First derivation with respect to $\mathrm{E}(\mathrm{t})$;

$\begin{array}{ll}0=e^{-p t} \frac{1}{\bar{E}} & +\quad \mu(\mathrm{t}) e^{-R(t)} \\ e^{-p t} \frac{1}{\bar{E}}= & -\mu(\mathrm{t}) e^{-R(t)}\end{array}$

Natural logarithm of both sides are taken;

$-p t-\ln E=\ln (-\mu(t))-R(t)$

Finally, second derivative with respect to $t$ gives the solution below; ${ }^{17}$

$-p-E^{\prime} / E=-R(t)^{\prime}$

If the change in expenditure is left alone on the right hand side. Growth rate of consumer expenditure can be observed explicitly.

$\mathrm{R}(\mathrm{t})^{\prime}-\mathrm{p}=\mathrm{E}^{\prime} / \mathrm{E}$

$17 \mu$ is omitted in the second derivation because it is constant. It can be proven by deriving Hamiltonian with respect to state variable; $\mathrm{dH} / \mathrm{dy}=-\mu^{\prime}=0$ 


\section{Production Side}

In this model, properties of vertical innovation and monopolistic competition can be observed.

- New products make the old ones obsolete.

- Quality leader charges mark-up price over marginal cost.

- There is imperfect competition.

- Amount of profit is the same in all industries so the competitors are indifferent choosing a market to enter.

\section{Profit Maximization}

It is assumed that because of the nature of the property rights in each industry there is a unique quality leader. This leader firm is exactly one step ahead of its closest rival. All "state of the art" products have the same price; $\mathrm{P}=\Lambda w$. Price yields demand per product of; $\mathrm{E} / \Lambda w$. The profit function of the firm is as follows;

$$
\begin{aligned}
& \pi=\mathrm{PE} / \Lambda w-\mathrm{wE} / \Lambda w \\
& \pi=\Lambda w \mathrm{E} / \Lambda w-\mathrm{wE} / \Lambda w \\
& \pi=\mathrm{E} / \Lambda w(\Lambda w-\mathrm{w}) \\
& \pi=(1-1 / \Lambda) E
\end{aligned}
$$

Firms in an industry compete each other in order to innovate the next step in the quality ladder for a targeted product. If a firm keeps R\&D intensity i for the time interval dt, it will reach the next step in the quality ladder with a probability idt. A unit of R\&D activity requires $\alpha_{i}$ unit of labor per unit of time. When the leader succeeds in a research project, it gains a two-step advantage over its closest rival. This situation gives leader the advantage to increase its price to $\Lambda^{2} w$. This situation causes a flow of marginal profit of leader equals to;

$\pi=\left(1-1 / \Lambda^{2}\right) E$

Profit before the research success is $\pi=(1-1 / \Lambda) E$. Thus the difference gives the incremental profit; $(1-1 / \Lambda) E / \Lambda$

This is clearly less than the profit that accrue to a non-leader who achieves a research success which equals to; $(1-1 / \Lambda) E$.

\section{R\&D Market}

The stock market value of the firm i.e. prize for a research success is given by v. Maximizing condition for the expected net benefit from R\&D equals to vidt - wa $\alpha_{i} i d t$. Aggregate intensity of 
research by the many entrepreneurs who target their R\&D efforts at the leader's product is given by i. Expected rate of return in shares per unit time equals to $\left(\pi-v^{\prime}\right) / v-i$.

No arbitrage condition can be written, using maximizing condition, $\mathrm{v}=\mathrm{wa}_{\mathrm{i}}$ as follows;

$\pi / w \alpha_{i}+w^{\prime} / w=R^{\prime}+i$

Finally, the relation between $R \& D$ market (production side) and spending (demand side) is shown below ${ }^{18}$;

$\pi / \alpha_{i}=R^{\prime}+i$

(13) and (9) are plugged into (15);

$\frac{\left(1-\frac{1}{\Lambda}\right) E}{a_{i}}=-p-E^{\prime} / E+i$

The growth in spending is left on the left hand side;

$\mathrm{E}^{\prime} / \mathrm{E}=\frac{\left(1-\frac{1}{\Lambda}\right) \bar{E}}{\mathrm{a}_{i}}-\mathrm{p}-\mathrm{i}$

When $\mathrm{E}^{\prime} / \mathrm{E}=0$ (no growth in spending) the initial condition equals to;

$\frac{\left(1-\frac{1}{\Lambda}\right) \bar{E}}{a_{i}}=\mathrm{p}+\mathrm{i}$

\section{Labor Market}

It is assumed that labor is employed in two sectors; manufacturing and $\mathrm{R} \& \mathrm{D}$. Total employment in manufacturing equals to $\int_{0}^{1} E(t) / P(t) d u=\mathrm{E}(\mathrm{t}) / \Lambda$ when total employment in R\&D sector equals to $\alpha_{i}$ i. Equilibrium in the labor market is given by;

$\alpha_{i} \mathrm{i}+\mathrm{E}(\mathrm{t}) / \Lambda=\mathrm{L}$

\section{Determinants of Growth Rate}

Solving (19) and (20) for i (Aggregate intensity of research) when there is no growth in spending i.e. $\mathrm{E} / \mathrm{E}=0$ gives;

$\mathrm{i}=\frac{\left(1-\frac{1}{\Lambda}\right) 2}{a_{i}}-\mathrm{p} / \Lambda$

A higher equilibrium can be achieved due to two terms in this equation;

- When there is a larger labor force, aggregate intensity of research grows faster.

- An increase in $\Lambda$ also causes a jump in technology and provides growth.

$18 \mathrm{w}(\mathrm{t})=1$ i.e. labor is taken as numeraire for all $\mathrm{t}$ 


\section{Optimal Growth Rate}

Lifetime utility function is presented as follows where $\mathrm{p}$ stands for the discount rate.

$\mathrm{pU}=\log \mathrm{E}-\log \Lambda+(i / \mathrm{p}) \log \Lambda$

Equation (22) is maximized subject to (20) with respect to i gives the optimal intensity of innovation ${ }^{19}$;

$\mathrm{i}^{*}=\mathrm{L} / \mathrm{a}_{\mathrm{i}}-\mathrm{p} / \log \Lambda$

Difference between Optimal and Equilibrium Growth Rate can be shown as follows;

$\mathrm{i}^{*}-\mathrm{i}=\mathrm{p} / \Lambda(\mathrm{L} / \mathrm{p} \alpha+1-\Lambda \log \Lambda)$

\section{Externalities}

The positive externality (consumer surplus + intertemporal spillover) is measured by $\log \Lambda / \mathrm{P}$. The negative externality is $(\Lambda-1) /(\mathrm{p}+\mathrm{i})$. The nominator shows the fall of other firms' profits caused by an innovation. Denominator is the discount rate with the expected rate of arrival of the next innovation. When the formula for difference between optimal and equilibrium growth rate is examined, it can be seen that a larger $\mathrm{L} / a$ (R\&D efficiency of labor) most probably leads to a higher optimal growth rate of aggregate innovation than the equilibrium rate.

19 E in equation $\mathrm{pU}=\log \mathrm{E}-\log \Lambda+(i / \mathrm{p}) \log \Lambda$ is substituted with $\mathrm{E}$ in subjective function, $\alpha_{\mathrm{i}} \mathrm{i}+\mathrm{E}(\mathrm{t}) / \Lambda=\mathrm{L}$. Then it is derived with respect to $i$. 
